\title{
NEW THEORIES OF CONSTITUTIONAL CONSTRUCTION
}

\section{By Thomas Raeburn White $\dagger$}

Recent decisions of the Supreme Court of the United States have had the effect of enormously increasing the power of the National Government, particularly as relates to the control of economic affairs, the regulation of labor conditions, the control and regulation of interstate commerce and the power of taxation. Other decisions have had the effect of increasing the power of State governments in certain respects, particularly in dealing with economic affairs.

How have these great and fundamental changes been brought about? Mainly by the application of theories of constitutional construction which differ substantially from those by which the court was guided in earlier cases.

The original conception of judicial review was that the courts should compare the applicable clause of the Constitution with a challenged statute and from a consideration of the words alone, decide whether the two were in conflict. This was the view of Hamilton as expressed in "The Federalist"; ${ }^{1}$ and this line of reasoning was adopted by Marshall in Marbury v. Madison ${ }^{2}$ without discussing the serious difficulties which have troubled other judges and other jurists, especially in Europe, arising from the fact that the function of the American courts may involve setting aside a legislative act. ${ }^{3}$

In United States $v$. Fisher et al., ${ }^{4}$ however, the court held that it must consider facts related to the subject in hand and not merely the words of the Constitution and the statute. In this case Marshall for the first time advanced the doctrine that "Congress must possess the choice of means, and must be empowered to use any means which are in fact conducive to the exercise of a power granted by the Constitution." 5 This thought was further elaborated in Marshall's great opin-

† B. L., 1896, Earlham College; LL. B., I899, University of Pennsylvania ; member of the Philadelphia Bar.

I. THE FEDERALIST, No. 78 (Hallowell's ed. I857) 357 et seq.

2. I Cranch 137, 2 L. Ed. 60 (1803).

3. See ThaYer, JoHn MARSHali (Bost. Igor) 96 , ror, in which the great Chief Justice is gently chided by Professor Thayer for what he concedes to be important omissions in his treatment of the subject. Other cases and contemporary expressions of opinion on this point are collected by Professor Thayer, The Origin and Scope of the American Doctrine of Constitutional Law (I908) LEGAL EsSAYS 14, 15. The theory that the court's function is limited to examining the words of the statute and the Constitution has persisted, with some unacknowledged exceptions, almost to the present day. See opinion of the court in United States v. Butler, 297 U. S. I, 56 Sup. Ct. 312, 80 L. Ed. 477 (1936).

4. 2 Cranch 358,2 L. Ed. 304 ( 1805 ).

5. Id. at 396,2 L. Ed. at 317 . 
ion in McCulloch v. Maryland, ${ }^{6}$ in which he made it clear that the court, in deciding whether Congress had selected a lawful method of exercising a constitutional power, must consider not only the written words but also the condition of the nation and its needs. The Constitution is "intended to endure for ages to come, and, consequently, to be adapted to the various crises of human affairs" ; ${ }^{7}$ Congress must have the choice of means for carrying into execution any power granted to it by the Constitution and any means "appropriate," "plainly adapted," and "really calculated to effect any of the objects entrusted to the government" are constitutional. ${ }^{8}$

In all of this there is no suggestion that the court will do other than determine for itself upon the evidence before it or upon facts of general knowledge whether the means chosen by Congress are "conducive," "plainly adapted," or "really calculated to effect" the end sought.

But very early another principle appears by which the court is guided in passing upon the constitutionality of a law. This principle was referred to by Chief Justice Tilghman, of Pennsylvania, in I8I I as well settled. He said it was assumed by all courts of reputation "that an act of legislature is not to be declared void, unless the violation of the constitution is so manifest as to leave no room for reasonable doubt." 9

There are many cases which so hold. What is the significance of this rule? If the court comparing the Constitution with the law finds that the latter is in conflict with the former, why not say so, and hold the law void, without the necessity of further considering whether the conflict is beyond reasonable doubt? If the case relates to the construction of one of the constitutional clauses which leaves to Congress the choice of means for execution of a power granted to it, why should the court, before it can hold a law unconstitutional, find it necessary to decide not only that the means chosen by Congress are not "plainly adapted" to the end sought, but that this is so beyond a reasonable doubt?

The mere fact that, as sometimes said, a decent respect for a co-ordinate department of government should require the courts to use great discretion in holding void the acts of such co-ordinate department does not sufficiently explain. The true reason for the rule is rather to
6. 4 Wheaton 316,4 L. Ed. 579 (I8I9).
7. Id. at $4 \mathrm{I} 5,4 \mathrm{~L}$. Ed. at 603 .
8. Id. at 42I, 423,4 L. Ed. at 605 .
9. Commonwealth v. Smith, 4 Binney II7, I23 (I8Ir). 
be deduced from the peculiar and unique nature of the court's power under our system to pass upon the validity of an act of legislation. ${ }^{10}$

The function of our courts is more than a mere comparison of the Constitution and the law; it is a review of the act of a co-ordinate department which has already passed upon the constitutionality of the statute and found it valid. Professor James Bradley Thayer says, "the ultimate question is not what is the true meaning of the Constitution, but whether legislation is sustainable or not." 11

This may be a rather extreme way of expressing the matter, but the fact must be recognized that the Constitution is equally binding on legislature and on court, and that when the legislative body has passed the law it has thereby expressed its judgment that it is constitutional.

The courts, therefore, in considering the question whether a legislative act is valid, which Marshall said could not be approached "without a deep sense of its importance, and of the awful responsibility inrolved in its decision," 12 are really considering not entirely what their own view of the meaning of the statute and the Constitution may be, but whether the conclusion of the legislature is clearly wrong beyond all doubt. The attitude of the court is not unlike that of a court of appeal in reviewing the verdict of a jury. The verdict will not be set aside if there is any substantial evidence to support it, even though the court of appeal may disagree with it.

This principle that an act of legislature will not be set aside as unconstitutional, except in a very clear case, has been somewhat expanded in recent years. Until quite recently the so-called conservative wing of the Supreme Court, while affirming the doctrine that in cases of doubt the statute nust not be overturned, held that the doubt must be a doubt in the minds of the judges themselves, and that if a judge was clear in his own mind that a law was in violation of the Constitution, it was his duty to so declare, no matter what other men might think. This view of the case was well expressed by Mr. Justice Sutherland in his dissenting opinion in West Coast Hotel Company v. Parrish. ${ }^{13}$ He said that the judge, in passing upon the validity of a statute, "discharges a duty imposed upon him, which cannot be consummated justly by an automatic acceptance of the views of others which have neither convinced, nor created a reasonable doubt in, his mind."

Io. See Thayer, The Origin and Scope of the American Doctrine of Constitutional Law (igO8) LEGAL EsSAYS I.

II. Id. at 30 .

I2. McCulloch v. Maryland, 4 Wheaton 316, 400, 4 L. Ed. 579, 600 (1819). See also Fletcher v. Peck, 6 Cranch 87, 3 L. Ed. 162 (I810).

13. 300 U. S. 379, 40I, 57 Sup. Ct. 578, 586, 8I L. Ed. 703, 714 (1936). 
On the other hand, certain of the Justices of the Supreme Court in prior years had expressed the opinion that it was the duty of the judge, at least in certain classes of cases, not merely to decide whether he had a doubt in his own mind, but whether a reasonable man could hold such a doubt. Possibly the earliest expression of this thought is contained in the dissenting opinion of Mr. Justice Holmes in the much discussed case of Lochner $v$. New York, ${ }^{14}$ in which the majority of the court held invalid a law limiting the hours of labor in bakeries to ten hours a day. It was held that the statute violated liberty of contract. Mr. Justice Holmes said: ${ }^{15}$

"I think that the word liberty in the Fourteenth Amendment is perverted when it is held to prevent the natural outcome of a dominant opinion, unless it can be said that a rational and fair man necessarily would admit that the statute proposed would infringe fundamental principles as they have been understood by the traditions of our people and our law."

In Coppage v. Kansas, ${ }^{16}$ dissenting from a decision of the majority declaring invalid a Kansas statute making it a misdemeanor for an employer to require an employee to agree not to become or remain a member of a labor organization during the time of his employment, Mr. Justice Holmes said, referring to the belief of a workman that he could not secure a fair contract unless he belonged to a labor union, that if that belief "whether right or wrong, may be held by a reasonable man," it may be enforced by law and is not a violation of liberty of contract. ${ }^{17}$

Running all through these dissenting opinions of Mr. Justice Holmes is the thought that the court was not warranted in holding invalid legislation regulating economic conditions if a reasonable man could believe that such restrictions were no infringement of liberty. Later Mr. Justice Brandeis, Mr. Justice Stone and Mr. Justice Cardozo expressed themselves in a somewhat similar way. Mr. Justice Brandeis, in New State Ice Company v. Liebmann, ${ }^{18}$ in dissenting from the conclusion that legislative regulation of the manufacture of ice was not warranted because this business was not one affected with a public interest, said that while the declaration of the legislature that a business

I4. 198 U. S. 45,25 Sup. Ct. 539, 49 L. Ed. 937 (I905).

I5. Id. at 76,25 Sup. Ct. at 547,49 L. Ed. at 949 .

I6. 236 U. S. I, 27, 35 Sup. Ct. $240,248,59$ I. Ed. 44I, 45I (I9I5).

I7. See also dissenting opinions of Mr. Justice Holmes in Adair v. United States, 208 U. S. I6I, I91, 28 Sup. Ct. 277, 287, 52 L. Ed. 436, 449 (I908) ; Adkins v. Children's Hospital, $26 \mathrm{r}$ U. S. 525, 570-57r, 43 Sup. Ct. 394, 404, 67 L. Ed. 785, 80I-802 (1923); and Tyson and Bro. v. Banton, 273 U. S. 4I8, 446, 47 Sup. Ct. 426, 433, $7 \mathrm{I}$ L. Ed. 718,729 (I927).

I8. 285 U. S. 262,52 Sup. Ct. 37 r, 76 L. Ed. 747 (I932). 
is of a public nature and subject to regulation is not conclusive and is subject to judicial review, the conclusion of the legislature must be sustained if it could reasonably be decided that the business was of that character. ${ }^{19}$

In Tyson and Bro. v. Banton, ${ }^{20}$ the court held invalid a New York statute regulating the resale of theatre tickets. Mr. Justice (now Chief Justice) Stone said in a dissenting opinion that the case turned "upon considerations of economics about which there may be reasonable differences of opinion. Choice between these views takes us from the judicial to the legislative field. The judicial function ends when it is determined that there is basis for legislative action in a field not withheld from legislative power by the Constitution as interpreted by the decisions of this court."

These views are traceable to the influence of Professor Thayer. He wrote in 1893 in the essay above referred to ${ }^{21}$ that:

"The judicial function is merely that of fixing the outside border of reasonable legislative action, the boundary beyond which the taxing power, the power of eminent domain, police power, and legislative power in general, cannot go without violating the prohibitions of the constitution or crossing the line of its grants." 22

In a note to the same volume he says that in construing the commerce clause, the courts cannot control a legislative decision as to whether a given subject falls within national or state power "except in cases so clear that there cannot reasonably be two opinions." 23

The provisions of the Constitution which lend themselves to a construction of this kind are those which contain general clauses, the precise content or application of which may require the exercise of judgment not only as to the technical meaning of the language used, but as to the conditions to which it applies. This involves a consideration of fact as well as law.

Congress has power "To lay and collect Taxes, . . . to pay the Debts and provide for the common Defence and general Welfare of the United States." What is the general welfare and when may the collection of taxes or the spending of the moneys raised by taxation be legitimately held valid as a provision for the general welfare?

Congress has power to "regulate Commerce with foreign Nations, and among the several States." What is commerce and may the scope of its meaning vary from year to year?

19. Id. at $284-285,52$ Sup. Ct. at 377,76 L. Ed. at 757.

20. 273 U. S. $418,454,47$ Sup. Ct. $426,436,71$ L. Ed. 718, 733 (1927).

2I. Op. cit. supra, note Io.

22. Id. at 27.

23. Id. at 36 . 
The citizens of each State are "entitled to all Privileges and Immunities of Citizens in the several States." What are these privileges and immunities and are they always the same?

Congress is forbidden to pass any law "abridging the freedom of speech, or of the press." May the extent to which these rights are protected differ at different times, depending upon conditions? ${ }^{24}$

No person shall be deprived of "life, liberty, or property without due process of the law." What is liberty and what is due process?

Cruel and unusual punishments are forbidden. What are cruel and unusual punishments?

These questions depend in part upon the construction of the words of the Constitution, and also in some instances upon the sense of the community as related to these subjects which may change from year to year.

In the preface to his Cases on Constitutional Law prepared for Harvard students in I895, Professor Thayer says:

"The study of Constitutional Law is allied not merely with history, but with statecraft, and with the political problems of our great and complex national life."

Referring to the labor of judges in this field, he continues:

"Views that seem adequate at the time, are announced, applied, and developed; and yet, by and by, almost unperceived, they melt away in the light of later experience, and other doctrines take their place."

The late Mr. Justice Cardozo expressed the matter in this way:

"Does liberty mean the same thing for successive generations? May restraints that were arbitrary yesterday be useful and rational and therefore lawful today? May restraints that are arbitrary today become useful and rational and therefore lawful tomorrow? I have no doubt that the answer to these questions must be yes. ${ }^{25}$

$$
* \quad * \quad *
$$

"From all this, it results that the content of constitutional immunities ís not constant, but varies from age to age. ${ }^{26}$

24. In this connection it is interesting to note that Alexander Hamilton, in arguing against the necessity for a bill of rights, said: "What signifies a declaration, that 'the liberty of the press shall be inviolably preserved?' What is the liberty of the press? Who can give it any definition which would not leave the utmost latitude for evasion? I hold it to be impracticable; and from this I infer, that its security, whatever fine declarations may be inserted in any constitution respecting it, must altogether depend on public opinion, and on the general spirit of the people and of the government." THE FEDERALIST, No. 84 (Hallowell's ed. I857) 394.

25. Cardozo, The Nature of the Judicial Process (ig2I) 76-77.

26. $I d$. at $82-83$. 
"The courts, then, are free in marking the limits of the individual's immunities to shape their judgments in accordance with reason and justice. That does not mean that in judging the validity of statutes they are free to substitute their own ideas of reason and justice for those of the men and women whom they serve. Their standard must be an objective one. In such matters, the thing that counts is not what I believe to be right. It is what I may reasonably believe that some other man of normal intellect and conscience might reasonably look upon as right." 27

This "new conception of the significance of constitutional limitations in the domain of individual liberty" has not "emerged to recognition and to dominance" 28 without a struggle, but the recent decisions of the Supreme Court have made it clear that the new theory has not only been accepted but extended by that Court.

In Nebbia v. New York, ${ }^{29}$ it was held that a statute of the State of New York regulating prices for the sale of milk was valid, although previous decisions of the court had held that price regulation of businesses not affected with a public interest, as those words had been previously construed, was beyond the power of the legislature as being violation of liberty of contract. The opinion of the court was based in large part upon facts which it was said had been disclosed to the court regarding the condition of the milk business in the State of New York, and it was held that "guaranty of due process . . . demands only that the law shall not be unreasonable, arbitrary or capricious, and that the means selected shall have a real and substantial relation to the object sought to be attained. It results that a regulation valid for one sort of business, or in given circumstances, may be invalid for another sort, or for the same business under other circumstances, because the reasonableness of each regulation depends upon the relevant facts. ${ }^{30}$. .

27. Id. at $88-89$.

28. Cardozo, id. at 78. See the dissenting opinion of Mr. Justice Sutherland in Home Building and Loan Association v. Blaisdell, 290 U. S. 398, 448-449, 450, 54 Sup. Ct. 23I, 244, 78 L. Ed. 4I3, 434-435 (I934), reading in part as follows: "A provision of the Constitution, it is hardly necessary to say, does not admit of two distinctly opposite interpretations. It does not mean one thing at one time and an entirely different thing at another time. . . . This view, at once so rational in its application to the written word, and so necessary to the stability of constitutional principles, though from time to time challenged, has never, unless recently, been put within the realm of doubt by the decisions of this court. .... Chief Justice Taney, in Dred Scott v. Sanford, I9 How. 393,426 , said that while the Constitution remains unaltered it must be construed now as it was understood at the time of its adoption; that it is not only the same in words but the same in meaning, 'and as long as it continues to exist in its present form, it speaks not only in the same words, but with the same meaning and intent with which it spoke when it came from the hands of its framers, and was voted on and adopted by the people of the United States. Any other rule of construction would abrogate the judicial character of this court, and make it the mere reflex of the popular opinion or passion of the day." "

29. 29 I U. S. 502, 54 Sup. Ct. 505, 78 I. Ed. 940 (1934).

30. Id. at 525,54 Sup. Ct. at 5 I0-5II, 78 L. Ed. at 950. 
Price control, like any other form of regulation, is unconstitutional only if arbitrary, discriminatory, or demonstrably irrelevant to the policy the legislature is free to adopt, and hence an unnecessary and unwarranted interference with individual liberty." 31

In Norman v. Baltimore \& Ohio Railroad Co., ${ }^{32}$ the court sustained a joint resolution of Congress, providing that private obligations to pay amounts due thereunder in gold coin of a particular weight and fineness could be discharged by the payment in any coin or currency which at the time was legal tender. The court held that the resolution was passed pursuant to the power of Congress to regulate the currency and to establish the monetary system of the country; that so-called gold clauses contained in private contracts were an effort to interfere with the policy of Congress in that connection and were therefore invalid. The court said that the questions involved in the case came down to a single point,

"whether the gold clauses do constitute an actual interference with the monetary policy of the Congress in the light of its broad power to determine that policy. Whether they may be deemed to be such an interference depends upon an appraisement of economic conditions and upon determinations of questions of fact. With respect to those conditions and determinations, the Congress is entitled to its own judgment. We may inquire whether its action is arbitrary or capricious, that is, whether it has reasonable relation to a legitimate end." 33

The court finally answered in the negative the question whether the determination of Congress that these contract clauses were an interference with its monetary policy

"is so destitute of basis that the interdiction of the gold clauses must be deemed to be without any reasonable relation to the monetary policy adopted by the Congress." 34

The final sentence in the court's opinion was:

"We think that it is clearly shown that these clauses interfere with the exertion of the power granted to the Congress and certainly it is not established that the Congress arbitrarily or capriciously decided that such an interference existed." ${ }^{35}$

31. Id. at 539, 54 Sup. Ct. at 517,78 L. Ed. at 958 .

32. 294 U. S. 240, 55 Sup. Ct. 407,79 L. Ed. 885 (1935).

33. Id. at $3 \mathrm{II}, 55$ Sup. Ct. at $4 \mathrm{I} 7,79 \mathrm{I}$. Ed. at 904.

34. Id. at 3I3, 55 Sup. Ct. at $418,79 \mathrm{~L}$. Ed. at 905.

35. Id. at $3 I 6,55$ Sup. Ct. at $419,79 \mathrm{~L}$. Ed. at 906. In Perry v. United States, 294 U. S. 330, 55 Sup. Ct. 432, 79 L. Ed. 9 r2 (I935), we find the converse of this ruling. The court held that the above noted resolution of Congress, insofar as it undertook to abrogate the gold clause in United States bonds, was "invalid as beyond its power" and therefore void, although the plaintiff was denied relief on the ground that he had suffered no damage. 
Something of the same thought was evidently in the mind of the court in sustaining the validity of the National Labor Relations Act in National Labor Relations Board v. Jones \& Laughlin Steel Corporation and related cases. ${ }^{36}$ These cases sustained the power of Congress to regulate labor relations of companies engaged exclusively in manufacturing within a state on the theory that the manufacture of a product which was to become a part of the flow of interstate commerce was an activity which the Court could regulate under its power to regulate interstate commerce, and that a restraint for the purpose of preventing what was called an "unjust interference" with the right of contract between the employer and its employees could not "be considered arbitrary or capricious." 37

In Wickard et al. v. Filburn, ${ }^{38}$ the court sustained the revised Agricultural Adjustment Act as applied to the regulation of the growing of wheat in a case where it was conceded that the grain would not become a part of interstate commerce but would be consumed on the premises on the theory that Congress could "properly have considered" that interstate commerce would be affected thereby. In answer to the claim that the action of Congress constituted violation of due process, the court said:

"An Act of Congress is not to be refused application by the courts as arbitrary and capricious and forbidden by the Due Process Clause merely because it is deemed in a particular case to work an inequitable result." 39

In construing the taxing power of the Federal Government, the court's recent decisions have been along the same lines. In discussing the question whether a tax was an infringement of the due process and equal protection clauses, the court said in Carmichael et al. $v$. Southern Coal \& Coke Co.: ${ }^{40}$

"A legislature is not bound to tax every member of a class or none. It may make distinctions of degree having a rational basis, and when subjected to judicial scrutiny they must be presumed to rest on that basis if there is any conceivable state of facts which would support it.

"This restriction upon the judicial function, in passing on the constitutionality of statutes, is not artificial or irrational. A state legislature, in the enactment of laws, has the widest possible latitude within the limits of the Constitution." 41

36. 301 U. S. I, 49, 58, 57 Sup. Ct. 615, 642, 645, 8I L. Ed. 893, 918, 921 (1937).

37. Id. at 44, 57 Sup. Ct. at $627,8 \mathrm{I}$ L. Ed. at 915 .

38. 3I7 U. S. III, 63 Sup. Ct. 82, 87 L. Ed. 57 (I942).

39. Id. at 129-1 30, 63 Sup. Ct. at 9r, 87 L. Ed. at 67.

40. 30I U. S. 495,57 Sup. Ct. 868, 81 L. Ed. 1245 (1937).

4I. Id. at 509-510, 57 Sup. Ct. at 872, 8x L. Ed. at 1253. 
In Helvering v. Davis, ${ }^{42}$ sustaining the Social Security Act, the court held that the spending power could be used by Congress in its discretion "unless the choice is clearly wrong, a display of arbitrary power, not an exercise of judgment. This is now familiar law. 'When such a contention comes here we naturally require a showing that by no reasonable possibility can the challenged legislation fall within the wide range of discretion permitted to the Congress," "43 and the court added :

"Nor is the concept of the general welfare static. Needs that were narrow or parochial a century ago may be interwoven in our day with the well-being of the Nation. What is critical or urgent changes with the times." 44

The theory that the court should have a wider discretion in determining the validity of acts of legislation has been extended in other directions. Ever since Ex parte Milligan ${ }^{45}$ it had been the doctrine of the Supreme Court that the existence of an emergency did not enlarge the power of Congress. In that case the court, referring to the framers of the Constitution, said:

"Those great and good men foresaw that troublous times would arise, when rulers and people would become restive under restraint; and seek by sharp and decisive measures to accomplish ends deemed just and proper; and that the principles of constitutional liberty would be in peril unless established by irrepealable law." 48

and that

"No doctrine, involving more pernicious consequences, was ever invented by the wit of man than that any of its provisions can be suspended during any of the great exigencies of government." 47

Nevertheless, in Home Building and Loan Association v. Blaisdell et al., ${ }^{48}$ the court held that a Minnesota act for the relief of mortgage debtors, although violating the provision of the Constitution that

42. 301 U. S. 619, 57 Sup. Ct. 904, 8I L. Ed. r307 (1937).

43. Id. at 640-64I, 57 Sup. Ct. at $908,8 \mathrm{I} \mathrm{L}$. Ed. at I3I5.

44. Id. at 64I, 57 Sup. Ct. at 908-909, 8I L. Ed. at I3I5. Other cases expressing the same principle are McGoldrick v. Berwind-White Coal Mining Co., 309 U. S. 33, 60 Sup. Ct. 388, 84 L. Ed. 565 (I940); Sunshine Anthracite Coal Co. v. Adkins, 310 U. S. 38r, 60 Sup. Ct. 907, 84 L. Ed. 1263 (I940), in effect overruling Carter v. Carter Coal Co., 298 U. S. 238, 56 Sup. Ct. 855, 80 L. Ed. II60 (I936); United States v. Darby, 3I2 U. S. I00, 6I Sup. Ct. 45I, 85 L. Ed. 609 (I94I), in which the Fair Labor Standards Act of 1938 was sustained, overruling Hammer v. Dagenhart, 247 U. S. 25I, 38 Sup. Ct. 529, 62 L. Ed. IIOI (I9I8); Olsen v. Nebraska, 3I3 U. S. 236, 6I Sup. Ct. 862, 85 L. Ed. I305 (I94I), overruling Ribnik v. McBride, 277 U. S. 350, 48 Sup. Ct. 545, 72 L. Ed. 913 (I928); and other cases.

45. 4 Wall. 2, I8 L. Ed. 28I (I866).

$46 . I d$. at $120,18 \mathrm{~L}$. Ed. at 295.

47. Id. at I21, I8 L. Ed. at 295.

48. 290 U. S. 398,54 Sup. Ct. 23 I, 78 L. Ed. 413 (r934). 
no State shall pass any law impairing the obligation of contracts, was valid. The real basis of the court's decision is contained in the following words :

"The policy of protecting contracts against impairment presupposes the maintenance of a government by virtue of which contractual relations are worth while, - a government which retains adequate authority to secure the peace and good order of society." 49

Although the court said, in an opinion by the Chief Justice, that it did not depart from the doctrine that emergency "does not create power," it is impossible to escape the conclusion that the effect of the court's decision, if not to create power, was to permit its exercise in a manner forbidden by the Constitution in view of the economic emergency existing in the State of Minnesota.

Mr. Justice Sutherland, in his dissenting opinion, demonstrated beyond question that the conditions of emergency existing at the time the law was passed were no worse than those which existed at the time the Constitution was adopted. He concluded that the law must necessarily be held to be a violation of the Constitution. The court, however, holding that the contract clause was not "an absolute and utterly unqualified restriction of the State's protective power," concluded that "this legislation is clearly so reasonable as to be within the legislative competency." 50

Summed up, the conclusion of this case appears to be that when unusual conditions exist the court may sustain what it conceives to be a reasonable violation of the Constitution if it believes the law is necessary to maintain the existence of the government.

That these cases denote a substantial departure from principles previously followed is not open to question. In the construction of the clauses above noted, the court has, in effect, concluded that legislation will be sustained as constitutional if, taking into consideration conditions existing at the time, a reasonable man would not necessarily find it arbitrary or capricious, and it has even extended this doctrine to cases where there is an admitted violation of a constitutional clause if in the opinion of the court the act may be considered to be a reasonable device necessary to maintain the integrity of the government.

In reaching the conclusions which it has in the various instances cited, and others which cannot be discussed within the limits of this article, the court has disregarded the principle of stare decisis. It has 
overruled its own decisions in numerous cases, some of which had only recently been decided. In some instances the change of view by the court was due to a change of opinion of individual judges. The decision of the court in Nebbia v. New York ${ }^{51}$ in effect overruled New State Ice Co. v. Liebmann, ${ }^{52}$ decided only two years earlier. This involved a change of view by Chief Justice Hughes and Mr. Justice Roberts, they having voted in the majority in both cases. West Coast Hotel Co. v. Parrish ${ }^{53}$ overruled Adkins v. Children's Hospital ${ }^{54}$ and also Morehead v. New York ex rel. Tipaldo, ${ }^{55}$ decided only ten months earlier. In this case Mr. Justice Roberts had changed his view.

Chief Justice Hughes delivering the opinion for the court in $W$ est Coast Hotel Co. v. Parrish ${ }^{56}$ attempts to distinguish the Tipaldo case on the ground that in the earlier case the Supreme Court had not been asked to overrule Adkins v. Children's Hospital, ${ }^{57}$ but had only been asked to distinguish it. This distinction, or rather explanation, it is said by Professor Thomas Reed Powell, "is a story that should bring blushes to those who joined in the official narration;" 58 and one of the present members of the court, in a book published shortly before he became a member of the court, referred to the explanation as "a bit of face-saving." 58 Many cases have been overruled in principle, in some instances without citing them or explaining the reasons for the change of view. ${ }^{60}$

That these decisions have had the effect of enlarging legislative power in certain fields by practically nullifying constitutional restrictions upon it is clear. Professor Corwin, of Princeton, in an able and thoughtful discussion of many of these new decisions, concludes that

"Not again for a long time will the Court hold void an act of Congress against which nothing can be said by way of constitutional objection except that it invades the accustomed. field of state power and tends to upset the Federal Equilibrium. Not again for a long time will it set aside an act of Congress-any act that Congress is likely to pass-on the ground solely that it deprives persons of liberty 'unreasonably', and so without 'due process of law'.

51. 291 U. S. 50́2, 54 Sup. Ct. 505, 78 L. Ed. 940 (1934).

52. 285 U. S. 262, 52 Sup. Ct. 37 I, 76 L. Ed. 747 (1932).

53. 300 U. S. 379, 57 Sup. Ct. 578, 81 L. Ed. 703 (1937).

54. $26 \mathrm{I}$ U. S. 525, 43 Sup. Ct. 394, 67 L. Ed. 785 (r923).

55. 298 U. S. 587,56 Sup. Ct. 9 I8, 80 L. Ed. 1347 (I936).

.56. 300 U. S. 379, 57 Sup. Ct. 578, 8 I L. Ed. 703 (I937).

57. 26 I U. S. 525, 43 Sup. Ct. 394, 67 L. Ed. 785 (1923). $529,549$.

58. Powell, Some Aspects of American Constitutional Law (I940) 53 HARv. L. Rev.

59. Jackson, The Struggle for Judictal Supremacy (I94I) 208.

60. For example, Nebbia v. New York, 29I U. S. 502, 54 Sup. Ct. 505, 78 L. Ed. 940 (I934), overruled Munn v. Illinois, 94 U. S. II3, 24 L. Ed. 77 (I876), and a long line of cases following it, without any real explanation of the reasons for doing so. 
In a word, those doctrines of constitutional law which have been hitherto the chief sources of its broadly supervisory powers over congressional legislation have simply dried up, at least for the time being. If they still retain the spark of life, it is at least dormant." 61

Professor Corwin continues that this is only part of the story and gives it as his opinion that "the Court dominated by Mr. Roosevelt's appointees-seems deliberately bent on minimizing its constitutional function, not only in the field of congressional legislation, but more generally." 62

The view now held by the Supreme Court as to the proper method of construing certain clauses of the Constitution appears to involve the conclusion not only that they may be applied to new conditions as they arise, but that they may by construction be given a new and extended meaning. ${ }^{63}$ This is not in accord with views formerly held. Chief

6i. Corwin, Constitutional Revolutton, Ltd. (194i) 108.

62. Id. at 109. This view of Professor Corwin may be due in part to the fact that some members of the court seem to have a strong bias against the doctrine of judicial review. Mr. Justice Frankfurter, in delivering the opinion of the court in Minersville School District v. Gobitis, 310 U. S. 586, 600, 60 Sup. Ct. IoIo, Ior5, 84 L. Ed. I375, 1382 (1940) refers to judicial review as being "itself a limitation on popular government," and the volume above referred to, The Struggle for Judicial Supremacy, note 59 supra, written by Mr. Justice Jackson before his elevation to the bench, taken as a whole is a sharp criticism of the court for having unjustifiably, as he thought, nullified acts of Congress; he depicts the court as having wrongfully assumed power to nullify the aspirations of democracy. In discussing the case of Ashton v. Cameron County District, 298 U. S. 5I3, 56 Sup. Ct. 892, 80 L. Ed. 1309 (I936), he says, at p. I66: "This case illustrated the reckless extent to which the Court was interfering with the economic affairs of the country," and later, at p. I70, he refers to the court as "not simply anti-Congress," but "anti-Government." These references, of course, were to the so-called "old court" prior to the new appointments, but illustrate the point of view then held by one of its critics. It is argued by Professor Commager, of Columbia University, in a recent article that judicial review has no value and is only a hindrance to democracy. Commager, Judicial Review and Democracy (1943) 19 VA. Q. Rev. $4 \mathrm{I} 7$.

63. The critics of the "old court" complained that it had abrogated to itself the powers of a third house of legislature; that it struck down laws because it did not approve of them, not because they were in violation of the Constitution. The new theory accepts and attempts to rationalize this conception of the power of the court in certain fields. It does and must legislate, it is said, otherwise the Constitution cannot be adapted to changing conditions. See Cardozo, The Nature of the Judicial Process (I92I) 82 et seq.

This theory has been applied so far principally to laws which regulate economic affairs, including labor conditions, or which relate to taxation; recent cases in which laws were alleged to infringe the constitutional protection of freedom of speech or of the press have been discussed and decided along conventional lines with due regard for precedent.

Even on this point, however, there appears to be a difference of opinion among the justices of the court. For example, in West Virginia State Board of Education, etc., et al. v. Barnette et al., 319 U. S. 624, 639, 666-7,63 Sup. Ct. II78, II86, Ir98, 87 I. Ed. II7I, II79, II93 (I943), a "salute the Flag" case, which overruled Minersville School District v. Gobitis, 310 U. S. 586, 60 Sup. Ct. IoIo, 84 L. Ed. I375 (1940), decided only a few months previously, Mr. Justice Jackson, delivering the opinion of the court, said at p. II79: "Much of the vagueness of the due process clause disappears when the specific prohibitions of the First become its standard. The right of a State to regulate, for example, a public utility may well include, so far as the due process test is concerned, power to impose all of the restrictions which a legislature may have a 'rational basis' for adopting. But freedoms of speech and of press, of assembly, and 


\section{Justice Marshall, in Osborn $v$. The Bank of the United States, ${ }^{64}$ said:}

"Courts are the mere instruments of the law, and can will nothing. When they are said to exercise a discretion, it is a mere legal discretion, a discretion to be exercised in discerning the course prescribed by law; and, when that is discerned, it is the duty of the court to follow it. Juidicial power is never exercised for the purpose of giving effect to the will of the judge; always for the purpose of giving effect to the will of the legislature; or, in other words, to the will of the law." 85

Of this passage Mr. Justice Cardozo wrote in the volume above referred to:

of worship may not be infringed on such slender grounds. They are susceptible of restriction only to prevent grave and immediate danger to interests which the state may lawfully protect. It is important to note that while it is the Fourteenth Amendment which bears directly upon the State it is the more specific limiting principles of the First Amendment that finally govern this case."

Mr. Justice Frankfurter, however, in his dissenting opinion, applied the theory of reasonableness as envisioned by the legislature of Virginia to the case before the court. He said at p. II93: "I think I appreciate fully the objections to the law before us. But to deny that it presents a question upon which men might reasonably differ appears to me to be intolerance. And since men may so reasonably differ, I deem it beyond my constitutional power to assert my view of the wisdom of this law against the view of the State of West Virginia."

In Hirabayashi v. United States, 320 U. S. 8r, rro, 63 Sup. Ct. 1375, I390, 87 L. Ed. 1337, r352 (1943), the court applied the theory of reasonableness to orders of military authorities restricting the activities of citizens of Japanese ancestry, which were attacked as a violation of the liberty guaranteed by the Constitution. The case went strictly on the ground of military necessity, but there were expressions in the opinions of some of the justices indicating that it must not be supposed from the decision of the court that "provisions of the Constitution protecting essential liberties are suspended by the mere existence of a state of war. It has been frequently stated and recognized by this Court that the war power, like the other great substantive powers of government, is subject to the limitations of the Constitution." Concurring opinion of $\mathrm{Mr}$. Justice Murphy, citing Ex parte Milligan, 4 Wall. 2, 18 L. Ed. 28I (I866).

In Skinner v. Oklahoma, 316 U. S. 535, 62 Sup. Ct. IIIo, 86 L. Ed. I655 (I942), the court, in holding invalid a statute of Oklahoma providing for the sterilization of habitual criminals, applied its own judgment and did not accept the judgment of the legislature of Oklahoma as to whether the law made invidious discriminations in its application or violated the due process clause in not affording an adequate hearing to a criminal before the sentence of sterilization was imposed.

64. 9 Wheaton 738, 866, 6 L. Ed. 204, 234 (I824).

65. A late expression of this view is contained in the dissenting opinion of $\mathrm{Mr}$. Justice Sutherland in West Coast Hotel Co. v. Parrish, 300 U. S. 379, 402-403, 404, 57 Sup. Ct. 578, 587, 8I I. Ed. 703, 714, 715 (I937). He said: "It is urged that the question involved should not receive fresh consideration, among other reasons, because of 'the economic conditions which have supervened'; but the meaning of the Constitution does not change with the ebb and flow of economic events. We frequently are told in more general -words that the Constitution must be construed in the light of the present. If by that it is meant that the Constitution is made up of living words that apply to every new condition which they include, the statement is quite true. But to say, if that be intended, that the words of the Constitution mean today what they did not mean when written-that is, that they do not apply to a situation now to which they would have applied then-is to rob that instrument of the essential element which continues it in force as the people have made it until they, and not their official agents, have made it otherwise. - . The judicial function is that of interpretation; it does not include the power of amendment under the guise of interpretation. To miss the point of difference between the two is to miss all that the phrase 'supreme law of the land' stands for and to convert what was intended as inescapable and enduring mandates into mere moral reflections."

In this opinion Mr. Justice Sutherland cites a number of authorities including Cooley on the Constitution, which fully sustain the view he expresses on this point. 
"It has a lofty sound; it is well and finely said; but it can never be more than partly true." 66

A recent author asserts that the meaning of the Constitution actually changes with the passing of the years and cites in support of his thesis the often quoted remark of Charles Evans Hughes that "we are under a constitution, but the Constitution is what the judges say it is." ${ }^{87}$ One is reminded of the cynical political quip of some years ago: "What is the Constitution between friends?" and of the opening sentence of Sir Francis Bacon's Essay on Truth: "What is Truth? said jesting Pilate; and would not stay for an answer." 68

The substance of the new theory of constitutional construction is that the guarantees of personal liberty, or at least some of them, and even certain clauses which mark the division of powers between the Federal and State governments have no definite or fixed meaning, but that their content may vary from time to time depending upon the changing condition of affairs; that any statute purporting to regulate economic affairs or labor conditions, or to promote the general welfare, or in certain other fields to which reference has been made, will not be held unconstitutional if a reasonable man could believe on "any conceivable state of facts" that it is not arbitrary and capricious. Whether a reasonable man could entertain such a belief would depend in part at least upon prevailing public opinion which changes from day to day. Since the legislature has passed the law and the Executive has approved it, what becomes of the constitutional guaranty? Are the legislators and executives (or at least some of them) not reasonable men? Is the court therefore powerless to interfere? ${ }^{69}$

This conception of the place of the judiciary in the American system of constitutional law is quite different from that originally held by our early jurists.

It has been recognized from the foundation of our government that the only way constitutional restrictions on the power of the Legislative or the Executive departments can be enforced is through the courts, and that maintaining the integrity of the Constitution depends

66. Cardozo, The Nature of the Judictar Process (igar) ifg.

67. Addresses and Papers of Charles E. Hughes (I908) I39. See Jacobus TEN BROEK, Use by the U. S. Supreme Court of Extrinsic Aids in Constitutionat Construction (1939) 27 CALIF. L. REv. 399. In this article the author says at p. 4II: ". - questions should be considered in the light of present-day conditions as they actually exist, not in the near darkness of the world as it surrounded the framers, nor yet in the dimming illumination of things as they were in the youth of the justices." The theory of the author seems to be that the sunlight of full understanding burst upon the world only within the last two or three decades.

68. I BACON, WORKS (Phila. I856) II.

69. Judge Cooley points out that the Fourteenth Amendment is "mere nonsense" if conformity to an act of legislation is in itself due process. Cooley, Constitutronal LIMITATIONS (7th ed. I903) 503. 
upon the firmness and honesty of an independent judiciary. Hamilton, in The Federalist, says:

"But it is easy to see, that it would require an uncommon portion of fortitude in the judges to do their duty as faithful guardians of the constitution, where legislative invasions of it had been instigated by the major voice of the community." 70

That the Judiciary department is the weakest of the three was fully recognized and every effort made to make the judges independent. Some of the early statesmen thought the courts would be unable to perform the duty laid upon them. Mr. Justice Gibson, in Eakin v. Raub ${ }^{71}$ said in a dissenting opinion, in which he argued against the power of judicial review of Acts of Congress :

"Once let public opinion be so corrupt, as to sanction every misconstruction of the constitution, and abuse of power, which the temptation of the moment may dictate, and the party which may happen to be predominant, will laugh at the puny efforts of a dependent power to arrest it in its course."

Of course, if the judges are not strong enough to resist pressure from the Legislative or Executive departments, or the force of public opinion, the restraints of the Constitution are weakened or destroyed altogether. The same thing is true if the court becomes the instrument of a political party or group and shows bias in its decisions, in which case it "loses its moral authority, and decisions which might be justified on grounds of policy excite natural indignation and suspicion when they are seen not to be fully justified on grounds of law." 72

The possibility that the courts might be influenced by political considerations in rendering decisions was warned against by James Wilson, who said:

"Nothing is more to be dreaded than maxims of law and reasons of state blended together by judicial authority. Among all the terrible instruments of arbitrary power, decisions of courts, whetted and guided and impelled by considerations of policy, cut with the keenest edge, and inflict the deepest and most deadly wounds." 73

The Supreme Court of the United States has been accused at various times in its history of allowing political considerations to influence its judgment. Prior to the Civil War it was commonly believed

70. The Federalist, No. 78 (Hallowell's ed. i857) 359.

71. I2 S. \& R. 330,355 (1825).

72. DICEY, THE LAW OF THE CONSTITUTION (7th ed. 1908) 172-I73.

73. I am indebted to my friend, Theodore W. Reath, Esq., for this statement of James Wilson, which was made in a lecture at the Law School of the University of Pennsylvania in 1792. 
that the Supreme Court had become the instrument of the slave power, and its decision in Dred Scott v. Sanford ${ }^{74}$ was generally ascribed to that fact. The opinion of the court, perhaps too pointedly, denies that it was influenced in any way by questions of policy in rendering its decision, but the dissenting opinion of Mr. Justice McLean strongly intimates that "an excited public opinion" had influenced a reversal of decisions by the Supreme Court of Missouri which the majority opinion held the Supreme Court was bound to follow. ${ }^{75}$

Professor Corwin refers to this decision as of "discreditable character as a judicial utterance," and concludes that while it cannot be designated a usurpation, it was "a gross abuse of trust by the body which rendered it." He points out that the Supreme Court was greatly injured in reputation by the decision, and continues:

"The court itself was conscious of its weakness, yet notwithstanding its prudent disposition to remain in the background, at no time since Jefferson's first administration has its independence been in greater jeopardy than in the decade between 1860 and 1870 ; so slow and laborious was its task of recuperating its shattered reputation." 76

The decision in the Legal Tender Cases, ${ }^{77}$ overruling Hepburn v. Griswold, ${ }^{78}$ after the appointment of two new judges to the bench and within a very short period of time, was thought to be influenced by political considerations, and that decision in the opinion of Charles Evans Hughes "shook popular respect for the court." 79

Justice Hughes also says, referring to the income tax decision in Pollock v. Farmers' Loan \& Trust Co.: ${ }^{80}$

"There can be no objection to a conscientious judge changing his vote, but the decision of such an important question by a majority

74. 19 How. 393, I5 L. Ed. 691 (1856).

75. Id. at $563,15 \mathrm{~L}$. Ed. at 766 .

76. CoRWin, The Doctrine of Judictal Review (I9I4) I57.

77. I2 Wall. 457, 20 L. Ed. 287 (I870).

78. 8 Wall. 603 , 19 L. Ed. 5r3 (1869).

79. Hughes, The Supreme Court of the United States (I928) 52. At this point Justice Hughes also says, referring to the fact that the reversal took place so soon after the original decision: "Stability in judicial opinions is of no little importance in maintaining respect for the Court's work." The view of Mr. Chief Justice Hughes on this point seems to have changed prior to his opinion for the court in the case of West Coast Hotel Co. v. Parrish, 300 U. S. 379, 57 Sup. Ct. 578, 8r L. Ed. 703 (1936), in which, as above noted, a case which was decided only ten months before was overruled after a change of view by one member of the court.

It is interesting to note that Mr. Justice Field, in his dissenting opinion in the Legal Tender Cases said: "I shall not comment upon the causes which have led to a reversal of that judgment [Hepburn v. Griswold]. They are patent to every one." Legal Tender Cases, I2 Wall. 457, 634, $20 \mathrm{~L}$. Ed. 287, 339 (1870).

80. I57 U. S. 429, I5 Sup. Ct. 673, 39 L. Ed. 759, also I,58 U. S. 601, I5 Sup. Ct. 912,39 L. Ed. I108 (1895). 
of one after one judge had changed his vote aroused a criticism of the Court which has never been entirely stilled." 81

During the period from I870 to I930, the court was criticized by a small but vocal group for decisions which it was said were based in part upon the views of the judges upon economic questions rather than a just construction of the words of the Constitution, but there was never any contention that the court's decisions had been based upon subservience to the Legislature or the Executive or to popular opinion.

Since 1933 the court has undoubtedly been subjected to tremendous pressure both from the Legislative and Executive departments of the Government, and particularly during the depths of the depression, by public opinion, to sustain laws of Congress regulating business within the states far beyond anything previously attempted and laws of the States which appeared to violate constitutional clauses for the protection of individuals.

The court itself has not indicated that it was affected by such considerations, but the President, in a magazine article, made the statement that the change of view by the court prior to any new members of it having been appointed, was due to what he called "The Supreme Court Fight," in which he had charged the court with inefficiency and had proposed a reorganization involving the appointment of enough new justices to overrule the previous decisions of the court. ${ }^{82}$

Professor Corwin, in the volume previously referred to, says :

"Considerably more important, I surmise, in inducing the Justices-or certain of them-to restudy their position, than the Court proposal or the homily which was its prologue, was the outcome of the election of 1936, manifesting overwhelming popular approval of the New Deal. . . ." 83

It is, of course, impossible to say what considerations moved the justices of the "old court" to change their views or the new justices to sustain laws which would have been held unconstitutional if earlier decisions had been followed. In the former case it may have been such considerations as Professor Corwin mentions, or it may have been such as were suggested by James Bryce, writing fifty years ago:

"The Supreme Court feels the touch of public opinion. Opinion is stronger in America than anywhere else in the world, and judges are only men. To yield a little may be prudent, for the tree that cannot bend to the blast may be broken." 84

8I. Hughes, The Supreme Court of the United States (I928) 54.

82. See Franklin Delano Roosevelt, The Fight Goes On (Sept. I94I) ColıInR's.

83. Corwin, Constitutional Revolution, Lid. (I94i) 73.

84. I Bryce, The American Commonwealth (3d ed. i895) 273. 
But whatever the reasons may have been for the vote of the individual judges of the court, or whatever the process by which they reached their conclusions, the question of interest now is the future of judicial review and whether it can be an effective check upon unconstitutional legislation. ${ }^{85}$ If the new theory of constitutional construction has been correctly appraised, it comes very close to leaving the construction of certain clauses of the Constitution to Congress and the Executive for if the test is reasonableness, not as envisioned by the court, but as it might be envisioned by any normal man at the time the law was passed, not excluding the members of the legislature who passed it, there appears to be little room for the court to hold unconstitutional any act of legislation in certain fields. ${ }^{86}$

Under this theory of its duty the court has permitted Congress to regulate the affairs of individuals in the States in a manner and to an extent never before believed possible. It is respectfully suggested that the court may have failed sufficiently to take into consideration the human tendency of persons in possession of political power to construe what they want to do as being constitutional. It is universally recognized that restrictions on the power of a Congress and Executive which they themselves construe would be totally ineffective to prevent unconstitutional action. "I agree," said Hamilton, "that "there is no liberty, if the power of judging be not separated from the legislative and executive powers.' " 87

The framers of our Constitution and their immediate ancestors had suffered from the exercise of arbitrary power both in America and in other countries from which they came. They intended to preserve in the Constitution the great ideals of liberty and equality and to protect the individual from the exercise of arbitrary power even by the organs of government which they themselves set up. They also intended to preserve to the people of the various states the right to manage their local affairs without interference from the central government except where the power to do so had been delegated.

85. In this connection it is interesting to note that the state courts in numerous instances have followed decisions of the Supreme Court of the United States on Constitutional questions not because they agreed with the reasoning of the decisions, but because they thought it desirable to have the state decisions in harmony with those of the Federal Courts. See the opinion of the court in Pennsylvania Company v. Scott 346 $\mathrm{Pa}$. I3 (1942), and the very able and spirited dissenting opinion by Mr. Justice Drew, at p. 20.

86. See address by Frank J. Hogan (I939) 64 A. B. A. REP. 478, in which he expresses the opinion that hereafter "the American people must look to the legislature rather than the judiciary for the preservation of those liberties which can be preserved only by the observations of limitations upon the exercise of power."

87. The Feneralist, No. 78 (Hallowell's ed. I857) 356, citing I MontesQuieu, SPIRIT of LAWS I86; Eng. trans. by Nugent (I873) I74. 
There can be no doubt that the means which Congress or a legislature may adopt for carrying out a constitutional power may change from time to time, so that laws which would be unconstitutional at one stage of our history may be constitutional at a later date, and vice versa, but the Constitution itself cannot change in meaning; there must be some true construction of written words. The court cannot condone what it deems to be "reasonable" violations of the Constitution, without in effect altering its words; it cannot surrender its duty to determine upon its own judgment the meaning of constitutional clauses, or whether a statute is a reasonable and appropriate means of exercising a power possessed by the legislative body without giving up its function as the final interpreter of the Constitution. 